\title{
Inhibitive Effect on the Rate of Hydrolysis of Tetracaine by the Surfactant-Coated Magnetic Nanoparticles $\left(\mathrm{Fe}_{3} \mathrm{O}_{4}\right)$
}

\author{
Mohd Shaban Ansari, Kashif Raees, M. Z. A. Rafiquee** \\ Department of Applied Chemistry, Z.H. College of Engineering and Technology, Aligarh Muslim University, \\ Aligarh 202002, Uttar Pradesh, India \\ *Corresponding author: E-mail: drrafiquee@gmail.com
}

DOI: 10.5185/amlett.2021.041619

The influence of the magnetic nanoparticles $\mathrm{Fe}_{3} \mathrm{O}_{4}$ and surfactant coated nanoparticles on the rate of alkaline hydrolysis of tetracaine were investigated spectrophotometrically. The $\mathrm{Fe}_{3} \mathrm{O}_{4}$ nanoparticles were synthesized by co-precipitation method. These synthesized nanoparticles were characterized by physical techniques. The XRD patterns showed the crystalline nature and the presence of two bands at $635 \mathrm{~cm}^{-1}$ and $585 \mathrm{~cm}^{-1}$ were assigned to the $\mathrm{Fe}-\mathrm{O}$ bond vibrations in $\mathrm{Fe}_{3} \mathrm{O}_{4}$. The SEM and TEM studies confirmed the spherical structure of nanoparticles. The VSM studies show the magnetic nature. The reaction rate increased linearly with increase in $[\mathrm{NaOH}]$. The rate constant values decreased with the increase in the SDS coated $\mathrm{Fe}_{3} \mathrm{O}_{4}$ nanoparticles from $4.0 \times 10^{-4} \mathrm{~s}^{-1}$ to $1.1 \times 10^{-4} \mathrm{~s}^{-1}$ in the presence of PEC 1500 . Similarly, the increase in the amount of $\mathrm{CTABr}$ coated $\mathrm{Fe}_{3} \mathrm{O}_{4}$ nanoparticles decreased the rate constant values from $4.0 \times 10^{-4} \mathrm{~s}^{-1}$ to $1.02 \times 10^{-4} \mathrm{~s}^{-1}$ in the presence of PEC 1500. The binding constant and rate constant were found to be lower in SDS coated nanoparticles than the CTABr coated particles. The observed results for $\mathbf{k}_{\psi^{-}}$[surfactant] in the presence of magnetic nanoparticles and surfactant coated nanoparticles were treated using the pseudophase kinetic model.

\section{Introduction}

Magnetic nanoparticles presents many interesting properties that can be used in a wide variety of applications including catalysis, magnetic seals and inks, magnetic recording media, ferrofluids, targeted drug delivery, contrast agents for magnetic resonance imaging and therapeutic agents for cancer treatment and in biomedicine etc. [1-3]. These applications require the properties like specific sizes, shapes, surface characteristics and magnetic properties of the nanomaterials [4]. Magnetite nanoparticles has considerable role in the targeted drug delivery also [5-8]. These nanocatalysts have the ability to catalyze the organic reactions involving oxidations, carboncarbon coupling reactions, hydro-formylation reactions, epoxidation reactions, etc. [9-10]. The surface of the magnetic nanoparticles are often modified by coating with polymers, surfactants, starch, polyelectrolytes, etc. to enable them more suitable for cell separation, protein purification, environment and food analysis, organic and biochemical synthesis, industrial waste water treatment and in bio sciences, etc. [11-14]. The iron oxide nanoparticles are among the materials having more stability, more selective and efficient nanoparticles. It can be easily separated and recovered from the reaction medium by an external magnetic field.

Tetracaine is an ester containing drug which hydrolysed to form the para-aminobenzoic acid and dimethyl aminoethanol as primary metabolites. Tetracaine (amethocaine) is used to numb different parts of the body such as eyes, nose, throat, skin, etc. by blocking nerve signals and thus reduces the sensation of pain [15-17]. It is also used as popular spinal anesthesia. Its topical analgesic properties make it useful ophthalmic anaesthesia. Delivery of the anaesthetic drugs to the target has always been a challenging issue. Drug delivery through the nanoparticles to the target has been the subject of studies by large number of workers in the recent years [18-21]. Drug formulations containing nanoparticles require an extensive kinetics studies to explore the stabilities under the varying sets of conditions. Informations pertaining to the stability of drug with nanoparticles, degree of association, degradation products formed and the mechanism of the reaction can be investigated through the kinetics studies.

The present studies were undertaken with the aim to get an insight into the chemical stability, dispensability, and binding ability of tetracaine with iron oxide nanoparticles. Tetracaine degradation rates in the presence of $\mathrm{Fe}_{3} \mathrm{O}_{4}$ and $\mathrm{Fe}_{3} \mathrm{O}_{4}$ coated with surfactants (with cetyltrimethyl ammonium bromide; CTABr@ $\mathrm{Fe}_{3} \mathrm{O}_{4}$ and sodium dodecyl sulphate; SDS@ $\mathrm{Fe}_{3} \mathrm{O}_{4}$ ) under the different reaction conditions will provide further informations regarding the mechanism of the degradation of tetracaine and the nature of products formed. The partitioning of tetracaine in the different pseudophases can be obtained with the help of the analysis of the variation in the reaction rates in the presence of surfactants through the applications of pseudophase and pseudophase ions exchange models. Thus, the present 


\section{Advanced Materials Letters www.vbripress.com/aml}

investigations may be useful to develop the technique to deliver the drug with the help of nanoparticles to the target.

\section{Experimental}

\section{Materials}

Ferrous chloride dehydrate (99\%; CDH, New Delhi), Ferric chloride (97.0\%; CDH, New Delhi, India), liquor ammonia 25\% (Thermo Fisher Scientific, Mumbai, India), Sodium hydroxide pellets (97\%, Merck, Mumbai, India), CTABr (99\%, CDH, New Delhi, India), Tetracaine (98\%, TCI, Tokyo, Japan) and SDS (99\%; CDH, New Delhi, India) were taken as supplied. All the other chemicals were used as such for the experimental work without further purification. Doubly distilled water was used for the preparation of various solutions of $\mathrm{NaOH}$, SDS, CTABr, and ammonia. The stock solution of sodium hydroxide $\left(1.0 \mathrm{~mol} \mathrm{dm}^{-3}\right)$ was prepared in distilled water. The stock solutions of CTABr $\left(1.0 \times 10^{-2} \mathrm{~mol} \mathrm{dm}^{-3}\right)$ and SDS $\left(1.0 \times 10^{-2} \mathrm{~mol} \mathrm{dm}^{-3}\right)$ were prepared in doubly distilled water. Stock solution of tetracaine $\left(1.0 \times 10^{-3} \mathrm{~mol} \mathrm{dm}^{-3}\right)$ was prepared in $99.9 \%$ ethanol.

\section{Synthesis of $\mathrm{Fe}_{3} \mathrm{O}_{4}$ magnetic nanoparticles by co- precipitation method}

Magnetic nanoparticles have been synthesized by using coprecipitation method [22-24]. $20.0 \mathrm{~g}$ of $\mathrm{FeCl}_{3}(0.4 \mathrm{M})$ and $10.0 \mathrm{~g}$ of $\mathrm{FeCl}_{2} .2 \mathrm{H}_{2} \mathrm{O}(0.2 \mathrm{M})$ were taken into a $1000 \mathrm{~mL}$ conical flask containing $300 \mathrm{~mL}$ doubly distilled water. The mixture was purged with $\mathrm{N}_{2}$ gas to remove dissolved oxygen from the solution. The mixture was stirred for 60 minutes in order to mix $\mathrm{Fe}^{3+}$ and $\mathrm{Fe}^{2+}$ ions properly. Then, added $200 \mathrm{~mL}$ of $25 \%$ ammonium hydroxide solution drop wise into the conical vessel. To keep the environment inert, the $\mathrm{N}_{2}$ gas was passed into the mixture and over the surface. $2 \mathrm{M}$ of $\mathrm{NaOH}$ solution was then added to the mixture to raise the $\mathrm{pH}$ further high $(\sim 14)$. The temperature of the conical flask was raised to $70^{\circ} \mathrm{C}$ by heating on water bath and $\mathrm{N}_{2}$ gas was purged through the mixture. The precipitate appeared in the conical flask. It was filtered and washed with acetone and double distilled water. After filtration, the precipitate was left in a hot air oven at $70^{\circ} \mathrm{C}$ for $\sim 5$ hours. The synthesized nanoparticles were black in appearance. The formation of nanoparticles can be represented by the following reaction:

$$
\mathrm{Fe}^{2+}+2 \mathrm{Fe}^{3+}+8 \mathrm{OH}^{-} \longrightarrow \mathrm{Fe}_{3} \mathrm{O}_{4}+4 \mathrm{H}_{2} \mathrm{O}
$$

The synthesized nanoparticles were characterized to ensure the required material formation. In this precipitation method, the presence of traces of dissolved oxygen should be avoided through purging nitrogen gas otherwise the required product cannot be obtained.

\section{Synthesis of CTABr-modified and SDS-modified magnetic nanoparticles}

$0.40 \mathrm{M} \mathrm{FeCl}_{3} .6 \mathrm{H}_{2} \mathrm{O}(20 \mathrm{~g}), 0.20 \mathrm{M} \mathrm{FeCl}_{2} .4 \mathrm{H}_{2} \mathrm{O}(10 \mathrm{~g})$ and $0.10 \mathrm{M} \mathrm{CTABr}(10.92 \mathrm{~g})$ were taken into conical flask of $1.0 \mathrm{~L}$ capacity containing $300 \mathrm{~mL}$ doubly distilled water.
The overhead stirrer was used to mix these materials properly. The solution was stirred vigorously for 45 minutes under the atmosphere of nitrogen gas. Then $200 \mathrm{~mL}$ of $25 \%$ ammonium hydroxide solution was added drop wise into the above solution until the $\mathrm{pH}$ of the resulting solution reached 9-11. The $\mathrm{pH}$ of the reaction medium was further raised to 14 by adding $2.0 \mathrm{M} \mathrm{NaOH}$ solution drop wise. This mixture was then stirred vigorously under purging nitrogen gas for five hours. The black precipitate formed was filtered and washed with distilled water several times. To prepare SDS- modified $\mathrm{Fe}_{3} \mathrm{O}_{4} \mathrm{MNPs}$, the same procedure was adopted by using aqueous solutions of $0.10 \mathrm{M}(8.64 \mathrm{~g})$ SDS instead of $\mathrm{CTABr}$ solution in the above experiment.

\section{Equipments used for the characterizations of the synthesized CTABr-modified $\mathrm{Fe}_{3} \mathrm{O}_{4}$ and SDS-modified MNPS}

The X-ray Diffraction (XRD) studies on the synthesized $\mathrm{Fe}_{3} \mathrm{O}_{4}$ MNPs were carried out by using X-ray Diffractometer, MiniFlex II, Rigaku, Japan, equipped with a $\mathrm{Cu} \mathrm{K}_{\alpha}$ radiation source $(\lambda=1.5406 \mathrm{~nm})$. The FT-IR spectra of the nanoparticles were recorded by Nicolet iS50 FT-IR Spectrometer (Thermo Fisher Scientific, Madison, USA). Field Emission Scanning Electron Microscope (FESEM, JSM-7800F, JEOL, Japan) and Transmission Electron Microscope (HRTEM, Techno, FEI) were used for the characterization of nanoparticles, Vibrating Sample magnetometer (VSM LakeShore-7404) was used to measure the magnetic behaviour of MNPs.

\section{Kinetic experiments}

Genesis 10S UV/Visible spectrophotometer (Thermo Fisher Scientific, Medison, USA) having multiple cell holders were used to perform all the kinetic experiments. The absorbance of the samples were measured using a quartz cuvette of volume $3.0 \mathrm{~mL}$ and path length of $10 \mathrm{~mm}$. Thermo stated water-bath was used to equilibrate all the kinetics runs at constant temperature. The repetitive scans were recorded (Fig. 1) for the tetracaine hydrolysis in alkaline medium at the regular gap of 5 minutes for the mixture containing the solutions of tetracaine $\left(=4.0 \times 10^{-5}\right.$ mol dm$\left.)^{-3}\right)$ and $\mathrm{NaOH}\left(=5.0 \times 10^{-2} \mathrm{~mol} \mathrm{dm}^{-3}\right)$ at fixed temperature of $37^{\circ} \mathrm{C}$. The requisite amounts of the reaction mixtures (tetracaine, surfactant and nanoparticles) were taken in a three necked round bottom flask with a capacity of $100 \mathrm{~mL}$. The conical flasks containing tetracaine, surfactant, polyethylene glycol, $\mathrm{NaOH}$ were placed on the water-bath for 15 minutes to equilibrate the temperature before mixing them in a round bottom flask. The monitoring time of the reaction was started when $50 \%$ of the total of requisite quantity of the $\mathrm{NaOH}$ was mixed with the other reactants. Pseudo-first-order conditions with $\left[\mathrm{OH}^{-}\right] \gg$ [tetracaine] were maintained throughout the experiment. The decrease in absorbance at $315 \mathrm{~nm}$ was used as a parameter to trace the progression of the reaction. In (absorbance) versus time were plotted and its slope was used to calculate the pseudo-first-order rate 


\section{Advanced Materials Letters www.vbripress.com/aml}

constants. Triplicate run of each kinetic experiment were performed with the reproducible values of rate constant having error limits of approximately $5 \%$.

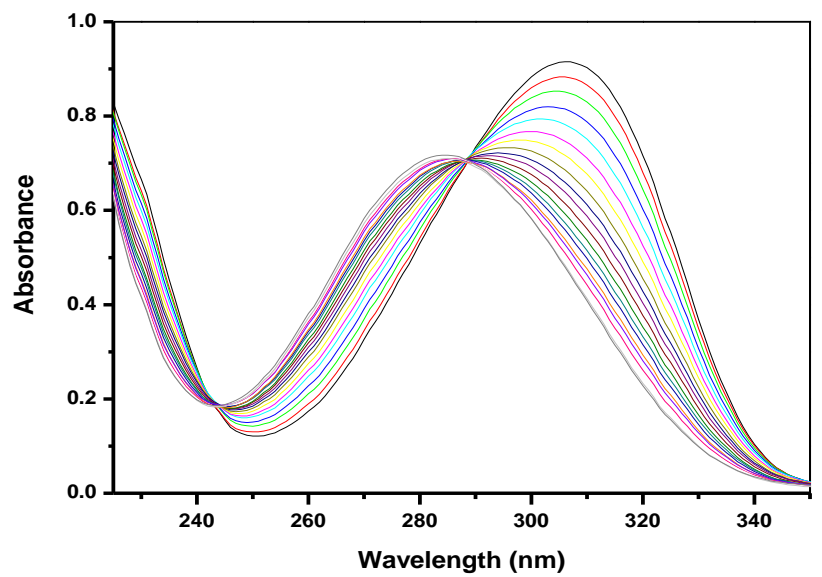

Fig. 1. The repetitive scans of the solution of tetracaine and $\mathrm{NaOH}$ at the interval of 5 minutes. Reaction conditions: [Tetracaine] $=4.0 \times 10^{-5} \mathrm{~mol}$ $\mathrm{dm}^{-3},[\mathrm{NaOH}]=5.0 \times 10^{-2} \mathrm{~mol} \mathrm{dm}{ }^{-3}$, Temperature $=37^{\circ} \mathrm{C}$.

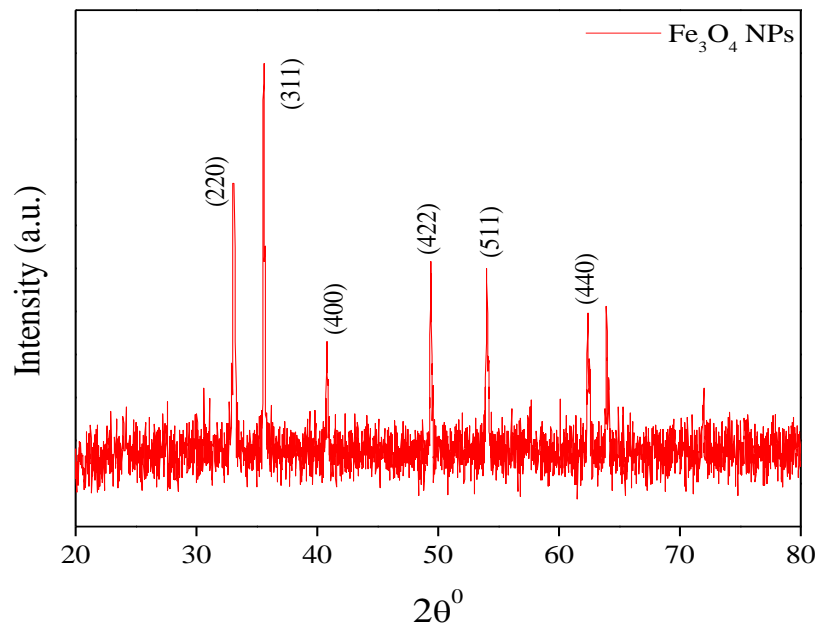

Fig. 2. The X-rays diffraction patterns obtained for $\mathrm{Fe}_{3} \mathrm{O}_{4}$.

\section{Results and discussion}

\section{Characterizations}

\section{$X$-ray Diffraction (XRD)}

The XRD patterns obtained for $\mathrm{Fe}_{3} \mathrm{O}_{4}$ are presented in Fig. 2, confirm the crystalline structure and phase purity of $\mathrm{Fe}_{3} \mathrm{O}_{4}$ nanoparticles. The diffraction peaks for $2 \theta$ values appeared at $30.26^{\circ}, 35.5^{\circ}, 43.12^{\circ}, 53.74^{\circ}, 57.10^{\circ}$ and $62.92^{\circ}$ which correspond to planes (220), (311), (400), (422), (511) and (440), respectively. The size of the particles was calculated by using the Scherrer Formula [25].

$$
\mathrm{D}=\frac{\mathrm{K} \lambda}{\beta \cos \theta}
$$

Here, in this equation, $\lambda$ is the wavelength of X-rays $(\lambda=1.5406 \mathrm{~nm}), \beta$ is the full width at half maximum (FWHM) value, $\mathrm{K}$ is Scherrer constant (0.89), $\theta$ is the angle of diffraction and $\mathrm{D}$ is the particle diameter size. The average particle size of $\mathrm{Fe}_{3} \mathrm{O}_{4}$ determined by using equation (1) was found to be $14.82 \mathrm{~nm}$.

\section{Fourier Transform Infrared Spectroscopy (FTIR)}

The FT-IR spectra of $\mathrm{Fe}_{3} \mathrm{O}_{4}, \mathrm{CTABr}$ modified $\mathrm{Fe}_{3} \mathrm{O}_{4}$ $\left(\mathrm{CTABr} @ \mathrm{Fe}_{3} \mathrm{O}_{4}\right)$ and SDS modified $\mathrm{Fe}_{3} \mathrm{O}_{4}\left(\mathrm{SDS} @ \mathrm{Fe}_{3} \mathrm{O}_{4}\right)$ are shown in Fig. 3. The presence of two strong absorption bands at $635 \mathrm{~cm}^{-1}$ and $585 \mathrm{~cm}^{-1}$ correspond to the $\mathrm{Fe}-\mathrm{O}$ bond vibration in $\mathrm{Fe}_{3} \mathrm{O}_{4}$ [26]. The appearance of absorption peak at $3424 \mathrm{~cm}^{-1}$ is due to the $\mathrm{O}-\mathrm{H}$ stretching vibration of hydroxyl group of water molecules associated with $\mathrm{Fe}_{3} \mathrm{O}_{4}$ [27]. The $\mathrm{H}-\mathrm{O}-\mathrm{H}$ bending of adsorbed water is visible by the appearance of peak at $1631 \mathrm{~cm}^{-1}$ in the $\mathrm{Fe}_{3} \mathrm{O}_{4}$ nanoparticles [28]. The $\mathrm{CTABr} @ \mathrm{Fe}_{3} \mathrm{O}_{4}$ nanoparticles display a peak at $582 \mathrm{~cm}^{-1}$ which corresponds to Fe-O. The presence of alkyl chains of CTABr appears at symmetric band at $1395 \mathrm{~cm}^{-1}$. The two peaks at $2845 \mathrm{~cm}^{-1}$ and $2922 \mathrm{~cm}^{-1}$ are attributed to two different band vibration of CTABr [29]. Antisymmetric vibrations of $\mathrm{N}\left(\mathrm{CH}_{3}\right)^{+}, \mathrm{C}-\mathrm{N}$, and $\mathrm{CH}_{3}{ }^{+}$stretching are found at $3015 \mathrm{~cm}^{-1}, 960 \mathrm{~cm}^{-1}$ and $1465 \mathrm{~cm}^{-1}$ [30]. The FTIR spectrum of SDS@ $\mathrm{Fe}_{3} \mathrm{O}_{4}$ nanoparticles displays a new absorption peak at $1252 \mathrm{~cm}^{-1}$ due to the stretching vibration of $\mathrm{S}=\mathrm{O}$ groups of SDS and the presence of peaks at $2929 \mathrm{~cm}^{-1}$ and $2842 \mathrm{~cm}^{-1}$ are assigned to the stretching mode for aliphatic $\mathrm{C}-\mathrm{H}$ groups of SDS [31]. The presence of peak at $529 \mathrm{~cm}^{-1}$ is attributed to $\mathrm{Fe}-\mathrm{O}$ of $\mathrm{Fe}_{3} \mathrm{O}_{4}$ [32]. The FTIR studies confirm the successful synthesis of $\mathrm{Fe}_{3} \mathrm{O}_{4}$ and their surface modifications through the adsorption of surfactants SDS and CTABr.

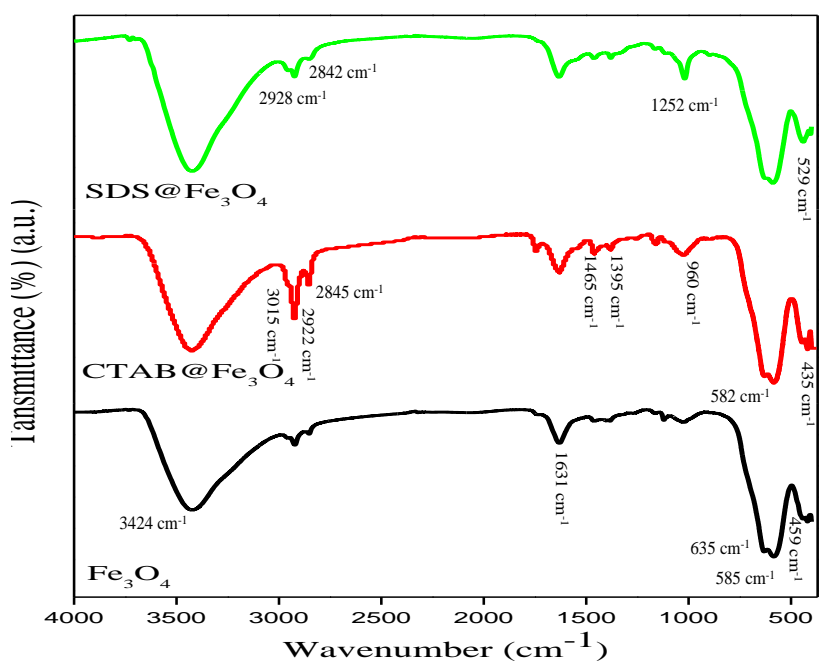

Fig. 3. The FT-IR spectra of $\mathrm{Fe}_{3} \mathrm{O}_{4}, \mathrm{CTABr} @ \mathrm{Fe}_{3} \mathrm{O}_{4}$ and $\mathrm{SDS} @ \mathrm{Fe}_{3} \mathrm{O}_{4}$

\section{Scanning Electron Microscopy (SEM)}

The SEM studies performed for the $\mathrm{Fe}_{3} \mathrm{O}_{4}$ nanoparticles, $\mathrm{CTABr} @ \mathrm{Fe}_{3} \mathrm{O}_{4}$ and $\mathrm{SDS} @ \mathrm{Fe}_{3} \mathrm{O}_{4}$ show that these nanoparticles have spherical irregular shape (Fig. 4). The $\mathrm{CTABr} @ \mathrm{Fe}_{3} \mathrm{O}_{4}$ and SDS@ $\mathrm{Fe}_{3} \mathrm{O}_{4}$ nanoparticles are smaller in size as compared to that of $\mathrm{Fe}_{3} \mathrm{O}_{4}$ particles, due to the agglomeration of many ultrafine particles. It can be observed that nanoparticles have the spherical morphology with low polydispersity and particle size lower than $100 \mathrm{~nm}$ as shown in Figs. 4(a-c). 


\section{Advanced Materials Letters www.vbripress.com/aml}

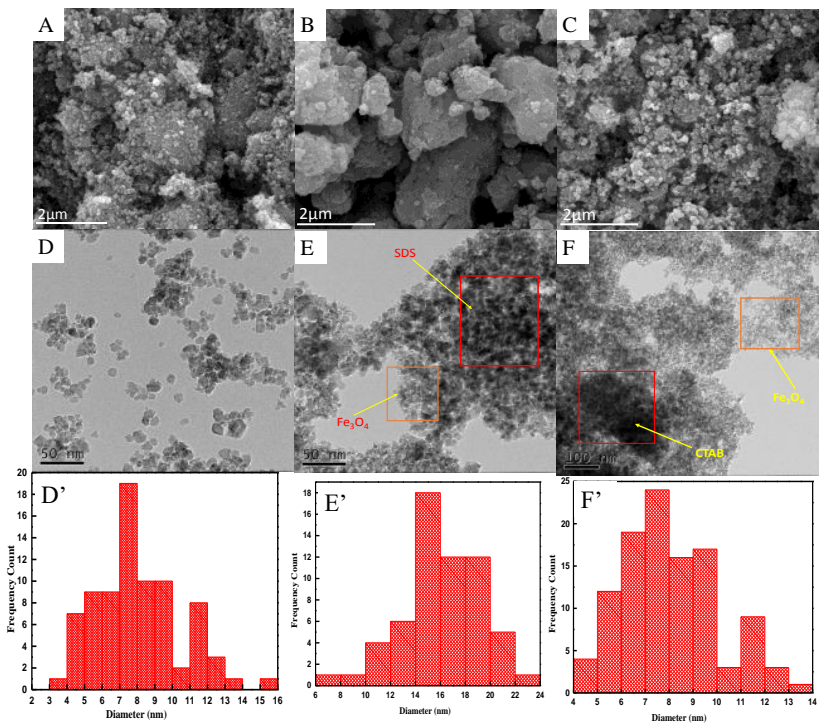

Fig. 4. SEM images of $\mathrm{Fe}_{3} \mathrm{O}_{4}(\mathrm{~A})$; $\mathrm{SDS} @ \mathrm{Fe}_{3} \mathrm{O}_{4}(\mathrm{~B})$ and $\mathrm{CTABr} @ \mathrm{Fe}_{3} \mathrm{O}_{4}(\mathrm{C})$; TEM images $\mathrm{Fe}_{3} \mathrm{O}_{4}(\mathrm{D})$; SDS@ $\mathrm{Fe}_{3} \mathrm{O}_{4}(\mathrm{E}) ; \mathrm{CTABr} @ \mathrm{Fe}_{3} \mathrm{O}_{4}(\mathrm{~F})$; Histogram images showing the size $\mathrm{Fe}_{3} \mathrm{O}_{4}(\mathrm{D}) ; \mathrm{SDS} @ \mathrm{Fe}_{3} \mathrm{O}_{4}(\mathrm{E}) ; \mathrm{CTABr} @ \mathrm{Fe}_{3} \mathrm{O}_{4}(\mathrm{~F})$.

\section{Transmission Electron Microscopy (TEM)}

The TEM images of $\mathrm{Fe}_{3} \mathrm{O}_{4}$ are shown in Fig. 4(d). The particles are spherical in shapes and the sizes vary in the range $10-20 \mathrm{~nm}$. Thus, a good agreement is observed in the shape and particle size for $\mathrm{Fe}_{3} \mathrm{O}_{4}$ by TEM and XRD spectrum calculated by using Scherrer Formula. The TEM images of CTABr@ $\mathrm{Fe}_{3} \mathrm{O}_{4}$ and $\mathrm{SDS} @ \mathrm{Fe}_{3} \mathrm{O}_{4}$ are shown in Figs. 4 (E-F). These images show a significant difference between the bare and modified nanoparticles. The coatings of $\mathrm{Fe}_{3} \mathrm{O}_{4}$ by $\mathrm{CTABr}$ and SDS reduce the particle size (CTABr@ $\mathrm{Fe}_{3} \mathrm{O}_{4} \sim 8 \mathrm{~nm}$; SDS@ $\mathrm{Fe}_{3} \mathrm{O}_{4} \sim 14 \mathrm{~nm}$ ).

\section{Vibrating Sample Magnetometer (VSM)}

The magnetic behavior of the $\mathrm{Fe}_{3} \mathrm{O}_{4}$ shows the saturation magnetization of nanoparticles at $40.00 \mathrm{emu} / \mathrm{g}$ (Fig. 5). This study indicates a very high saturation magnetization and super paramagnetic behavior of the nanoparticles [33].

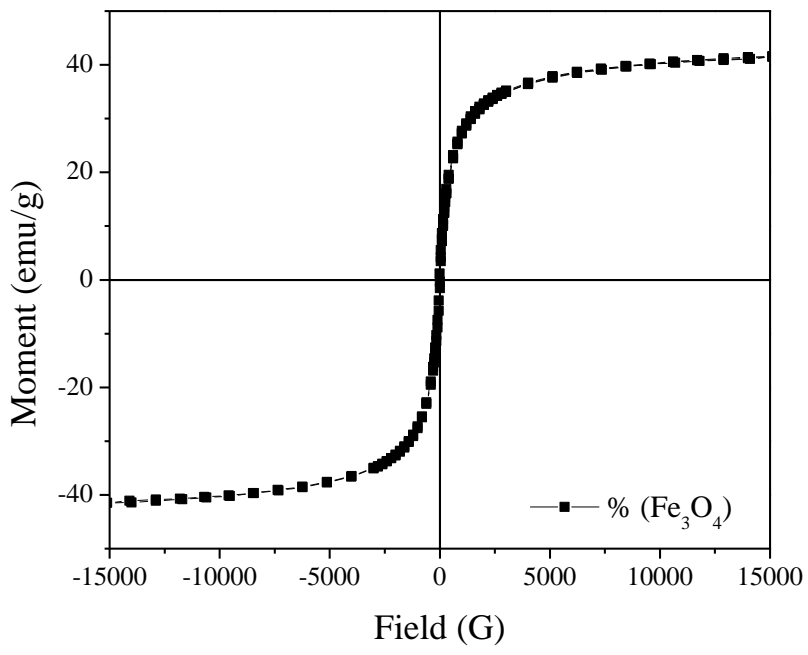

Fig. 5. Hysteresis curve for $\mathrm{Fe}_{3} \mathrm{O}_{4}$ at room temperature.

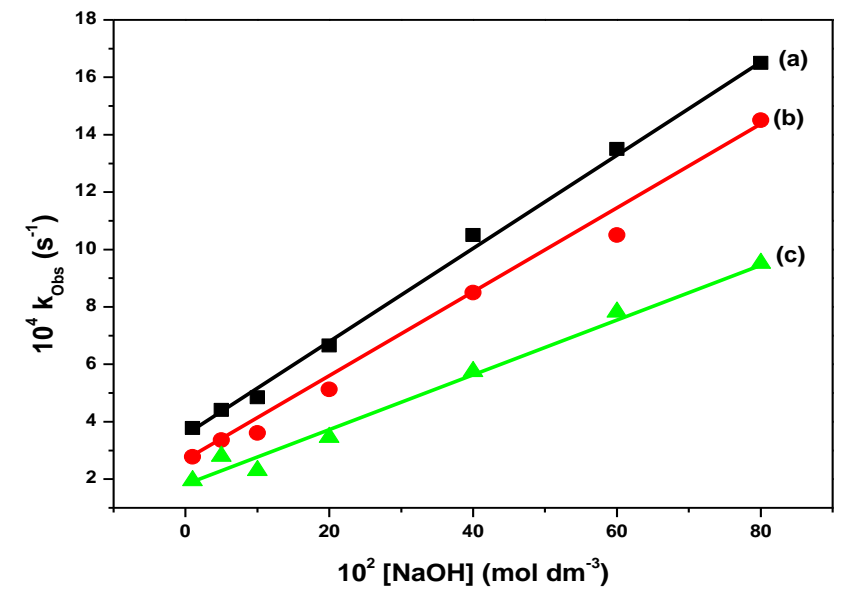

Fig. 6. Plots of $\mathrm{k}_{\mathrm{obs}}$ versus $[\mathrm{NaOH}]$ in the absence of $\mathrm{Fe}_{3} \mathrm{O}_{4}$ (a); in the presence of $0.2 \%(\mathrm{w} / \mathrm{v}) \mathrm{Fe}_{3} \mathrm{O}_{4}$ (b) and $0.4 \%$ (w/v) $\mathrm{Fe}_{3} \mathrm{O}_{4}(\mathrm{c})$. Reaction conditions: $[$ Tetracaine $]=4.0 \times 10^{-5} \mathrm{~mol} \mathrm{dm}^{-3}$ and Temperature $=37^{\circ} \mathrm{C}$.

\section{Influence of $\mathrm{Fe}_{3} \mathrm{O}_{4}$ nanoparticles and Surfactants on the Alkaline Hydrolysis of Tetrcaine}

The added iron nanoparticles into the solution containing $\mathrm{NaOH}$ and tetracaine decreased the rate constant values. The kinetics studies were performed using $0.2 \%$ and $0.4 \%$ (w/v) $\mathrm{Fe}_{3} \mathrm{O}_{4}$ at varying concentration of sodium hydroxide in the range from $1.0 \times 10^{-2} \mathrm{~mol} \mathrm{dm}^{-3}$ to $8.0 \times 10^{-1} \mathrm{~mol} \mathrm{dm}^{-3}$. Fig. 6 shows that the values of rate constant increased with increase in the concentration of sodium hydroxide. The values of rate constant in the presence of $\mathrm{Fe}_{3} \mathrm{O}_{4}$ were found to be lower than the corresponding values obtained in the absence of $\mathrm{Fe}_{3} \mathrm{O}_{4}$. The amount of $\mathrm{Fe}_{3} \mathrm{O}_{4}$ was changed from $0.02 \%$ to $0.40 \%(\mathrm{w} / \mathrm{v})$ keeping tetracaine and sodium hydroxide fixed at $4.0 \times 10^{-5} \mathrm{~mol} \mathrm{dm}^{-3}$ and $5.0 \times 10^{-2}$ accordingly. It has been observed that the increase in amount of $\mathrm{Fe}_{3} \mathrm{O}_{4}$ particles decreased rate constant values. The decrease in the rate constant values for the alkaline hydrolysis of tetracaine in the presence of $\mathrm{Fe}_{3} \mathrm{O}_{4}$ may be attributed to the inhibitive effect of $\mathrm{Fe}_{3} \mathrm{O}_{4}$ surfaces. The $\mathrm{Fe}_{3} \mathrm{O}_{4}$ may able to adsorb $\mathrm{OH}^{-}$ions and or tetracaine or both. The tetracaine molecules may get adsorbed to $\mathrm{Fe}_{3} \mathrm{O}_{4}$ and become less active for hydrolysis and so the reaction rate for the hydrolysis of tetracaine decreases. The tetracaine molecules in the presence of $\mathrm{Fe}_{3} \mathrm{O}_{4}$ are distributed into the aqueous medium and some of the molecules are adsorbed with $\mathrm{Fe}_{3} \mathrm{O}_{4}$ surface. The adsorption of tetracaine on $\mathrm{Fe}_{3} \mathrm{O}_{4}$ surface makes it unavailable for the $\mathrm{OH}^{-}$ions attack and therefore the rate of reaction for the hydrolysis of tetracaine decreases. The following mechanism is proposed (Scheme 1).

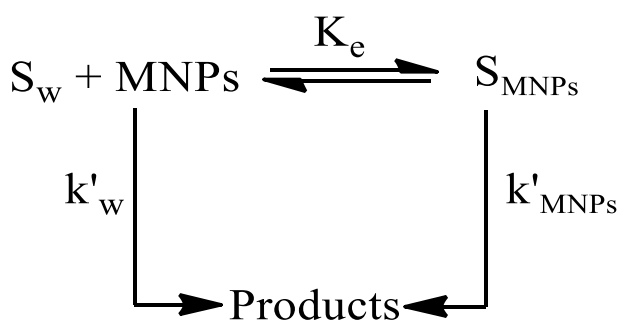

Scheme 1 


\section{Advanced Materials Letters www.vbripress.com/aml}

Where, $S_{\mathrm{w}}$ denotes free tetracaine present in the aqueous medium and $\mathrm{S}_{\mathrm{MNPs}}$ is the $\mathrm{Fe}_{3} \mathrm{O}_{4}$ bound tetracaine. $\mathrm{K}_{\mathrm{e}}$ is the equilibrium constant for the distribution of tetracaine occurring in the aqueous and adsorbed phase. The mechanism of the reaction is shown in Scheme 1, the overall reaction rate of given by:

$$
\text { Rate }=\mathrm{k}_{\mathrm{w}}^{\prime} \mathrm{S}_{\mathrm{w}}+\mathrm{k}_{\mathrm{MNPs}}^{\prime} \mathrm{S}_{\mathrm{MNPs}}
$$

where, $\mathrm{k}_{\mathrm{w}}^{\prime}$ and $\mathrm{k}_{\mathrm{MNPs}}^{\prime}$ are the first order reaction rate constant for the hydrolysis of tetracaine. The equilibrium distribution of tetracaine in aqueous medium and $\mathrm{Fe}_{3} \mathrm{O}_{4}$ bound can be given by equation (3)

$$
\mathrm{K}_{\mathrm{e}}=\frac{\left[\mathrm{S}_{\mathrm{MNPs}}\right]}{\left[\mathrm{S}_{\mathrm{w}}\right][\mathrm{MNPs}]}
$$

Equation (1) can be rewritten as

$$
\text { Rate }=\mathrm{k}_{\mathrm{w}}^{\prime} \mathrm{S}_{\mathrm{w}}+\mathrm{k}_{\mathrm{MNPs}}^{\prime} \mathrm{K}_{\mathrm{e}} \mathrm{S}_{\mathrm{w}} \text { [MNPs] }
$$

The total concentration of tetracaine is

$$
\left[\mathrm{S}_{\mathrm{w}}\right]_{\mathrm{T}}=\left[\mathrm{S}_{\mathrm{w}}\right]+\left[\mathrm{S}_{\mathrm{MNPs}}\right]
$$

Or,

$$
\left[\mathrm{S}_{\mathrm{w}}\right]_{\mathrm{T}}=\left[\mathrm{S}_{\mathrm{w}}\right]+\mathrm{K}_{\mathrm{e}}\left[\mathrm{S}_{\mathrm{w}}\right][\mathrm{MNPs}]
$$

Also, the rate of reaction for the alkaline hydrolysis in terms of primary tetracaine concentration, $\left[\mathrm{S}_{\mathrm{W}}\right]_{\mathrm{T}}$ is given by

$$
\text { Rate }=\mathrm{k}_{\psi}\left[\mathrm{S}_{\mathrm{w}}\right]_{\mathrm{T}}
$$

Where, $\mathrm{k}_{\psi}$ is the first order reaction rate constant and its values in terms of $\mathrm{k}_{\mathrm{w}}^{\prime}$ and $\mathrm{k}_{\text {spion }}^{\prime}$ can be deduced by using equations (4) and (6).

$\mathrm{Or}$,

$$
\mathrm{k}_{\Psi}=\frac{\mathrm{k}_{\mathrm{W}}^{\prime}+\mathrm{k}_{\mathrm{MNPs}}^{\prime} \mathrm{K}_{\mathrm{e}}[\mathrm{MNPs}]}{1+\mathrm{K}_{\mathrm{e}}[\mathrm{MNPs}]}
$$

On rearrangement of equation (7), we get:

$$
\frac{1}{\mathrm{k}_{\mathrm{w}}^{\prime}-\mathrm{k}_{\Psi}}=\frac{1}{\mathrm{k}_{\mathrm{w}}^{\prime}-\mathrm{k}_{\mathrm{MNPs}}^{\prime}}+\frac{1}{\left(\mathrm{k}_{\mathrm{w}}^{\prime}-\mathrm{k}_{\mathrm{MNPs}}^{\prime}\right) \mathrm{K}_{\mathrm{e}}[\mathrm{MNPs}]}
$$

The plot of $\frac{1}{\mathrm{k}_{\mathrm{w}}^{\prime}-\mathrm{k}_{\psi}}$ versus $\frac{1}{[\mathrm{MNPs}]}$ of equation (9) was used to determine the equilibrium constant $\left(\mathrm{K}_{\mathrm{e}}\right)$ for the binding of tetracaine withFe $\mathrm{O}_{3} \mathrm{O}_{4}$ from the slope of the plot. The values of $\mathrm{k}_{\mathrm{MNPs}}^{\prime}$ were calculated from the intercept and are given in Table 1.

Table 1. Values of $\mathrm{K}_{\mathrm{e}}$ obtained from the plots of $\frac{1}{\mathrm{k}_{\mathrm{w}}^{\prime}-\mathrm{k}_{\mathrm{MNPs}}}$ versus $\frac{1}{[\text { MNPs/surf-MNPs] }}$.

\begin{tabular}{ccc}
\hline Magnetic Nanoparticles & $\mathbf{K}_{\mathbf{e}}$ & $\left.\mathbf{1 0}^{\mathbf{5}} \mathbf{k}_{\text {MNPs }}^{\prime} \mathbf{s}^{-1}\right)$ \\
\hline $\mathrm{Fe}_{3} \mathrm{O}_{4}$ & 7.44 & 12.3 \\
$\mathrm{CTABr} @ \mathrm{Fe}_{3} \mathrm{O}_{4}$ & 38.7 & 9.8 \\
$\mathrm{SDS} @ \mathrm{Fe}_{3} \mathrm{O}_{4}$ & 42.4 & 2.5 \\
\hline
\end{tabular}

Reaction conditions: [Tetracaine $]=4.0 \times 10^{-5} \mathrm{~mol} \mathrm{dm}^{-3}[\mathrm{NaOH}]=5.0 \times$ $10^{-2} \mathrm{~mol} \mathrm{dm}-3$ and Temperature $=37^{\circ} \mathrm{C}$.

The influence of surfactants on the values of rate constants was also studied. The increase in surfactant concentration (CTABr and $\mathrm{SDS}$ ) into the solution containing, tetracaine, $\mathrm{NaOH}$ and $\mathrm{Fe}_{3} \mathrm{O}_{4}$ decreased rate of reaction for the hydrolysis of tetracaine. The [surfactant] was increased from $1.0 \times 10^{-2} \mathrm{~mol} \mathrm{dm}^{-3}$ to $5.0 \times 10^{-2} \mathrm{~mol} \mathrm{dm}^{-3}$ in the presence of $0.2 \%$ and $0.4 \%(\mathrm{w} / \mathrm{v}) \mathrm{Fe}_{3} \mathrm{O}_{4}$. Under the set of reaction condition, besides $\mathrm{Fe}_{3} \mathrm{O}_{4}$, the other microheterogeneous phases are micellar pseudophase and aqueous pseudophase. Tetracaine molecules are either solubilized into aqueous and micellar phases or adsorbed to the $\mathrm{Fe}_{3} \mathrm{O}_{4}$ surfaces. Similarly, some of the surfactant molecules are also adsorbed to the $\mathrm{Fe}_{3} \mathrm{O}_{4}$ surfaces and help to adsorb the tetracaine molecules more towards the $\mathrm{Fe}_{3} \mathrm{O}_{4}$ surfaces. Therefore, more inhibitive effect is found on the reaction rates for the alkaline hydrolysis of tetracaine in the presence of CTABr (Fig. 7). The reaction rate for the alkaline hydrolysis of tetracaine increases with increment in the concentration of SDS at constant $[\mathrm{NaOH}]$ in the presence of $0.2 \%$ and $0.4 \%(\mathrm{w} / \mathrm{v}) \mathrm{Fe}_{3} \mathrm{O}_{4}$ (Fig. 8). The increase in the rate of hydrolysis may be due to the poor binding of tetracaine with SDS and $\mathrm{Fe}_{3} \mathrm{O}_{4}$ surfaces and also due to the more competitive binding of hydroxide ions with the anionic SDS micelles and $\mathrm{Fe}_{3} \mathrm{O}_{4}$ nanoparticles and thus tetracaine remains mostly in the aqueous phase.

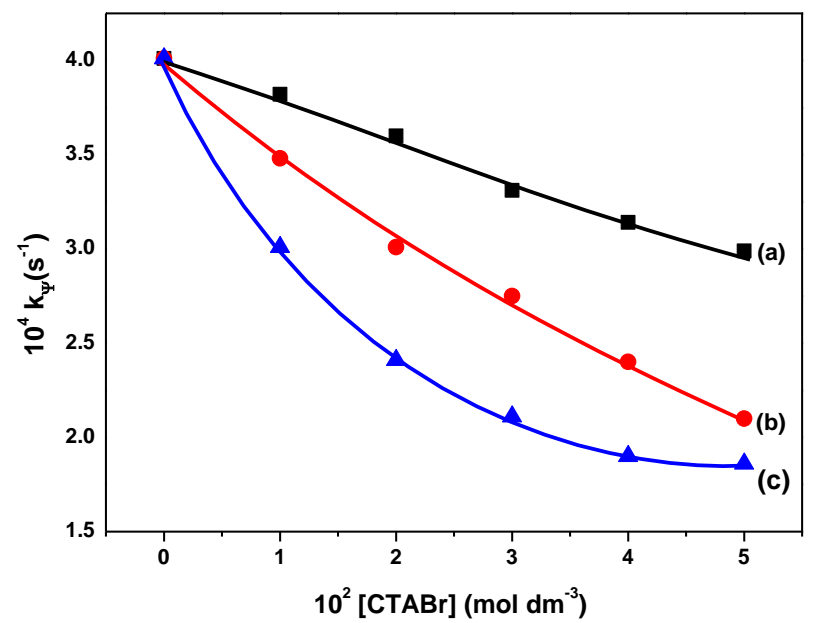

Fig. 7. Plots of $\mathrm{k}_{\psi}$ versus [CTABr] in the absence of $\mathrm{Fe}_{3} \mathrm{O}_{4}$ (a); in the presence of $\mathrm{Fe}_{3} \mathrm{O}_{4} 0.2 \%(\mathrm{w} / \mathrm{v})(\mathrm{b})$ and $(0.4 \% \mathrm{w} / \mathrm{v})$ (c) $\mathrm{Fe}_{3} \mathrm{O}_{4}$. Reaction conditions: $[$ Tetracaine $]=4.0 \times 10^{-5} \mathrm{~mol} \mathrm{dm}^{-3},[\mathrm{NaOH}]=5.0 \times 10^{-2} \mathrm{~mol}$ $\mathrm{dm}^{-3}$ and Temperature $=37^{\circ} \mathrm{C}$.

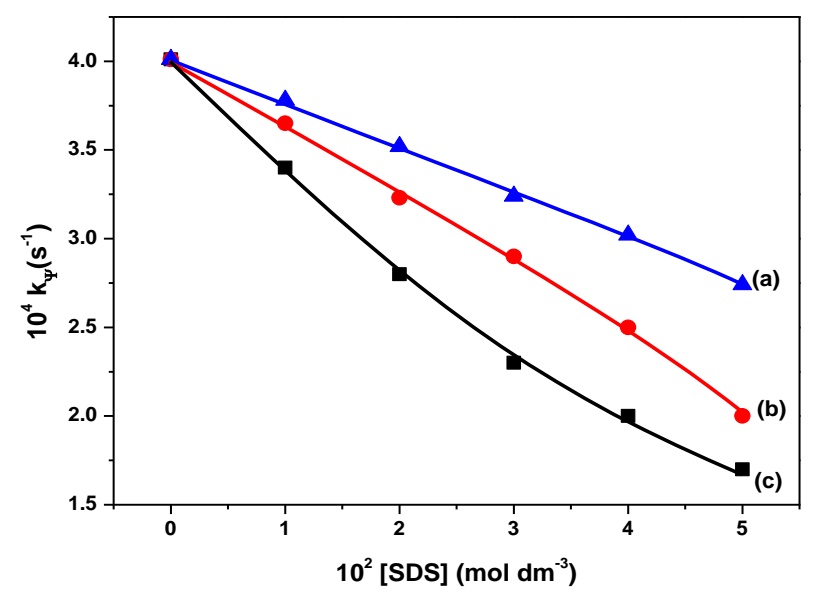

Fig. 8. Plots of $\mathrm{k}_{\psi}$ versus [SDS] in the absence of $\mathrm{Fe}_{3} \mathrm{O}_{4}(\mathrm{c})$; in the presence of $\mathrm{Fe}_{3} \mathrm{O}_{4} 0.2 \%(\mathrm{w} / \mathrm{v})(\mathrm{b})$ and $(0.4 \% \mathrm{w} / \mathrm{v})$ (a) $\mathrm{Fe}_{3} \mathrm{O}_{4}$. Reaction conditions: $[$ Tetracaine $]=4.0 \times 10^{-5} \mathrm{~mol} \mathrm{dm}{ }^{-3},[\mathrm{NaOH}]=5.0 \times 10^{-2} \mathrm{~mol} \mathrm{dm}^{-3}$ and Temperature $=37^{\circ} \mathrm{C}$. 


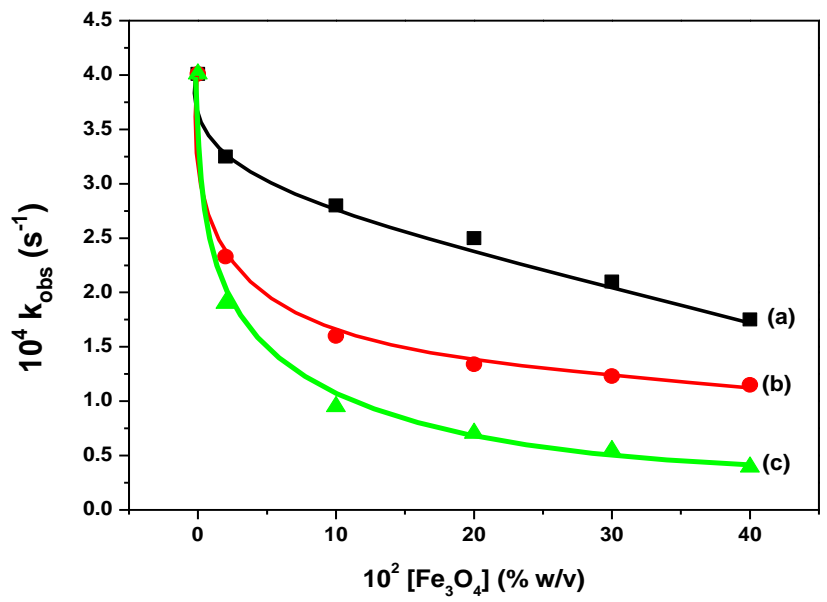

Fig. 9. Plots of $\mathrm{k}_{\mathrm{obs}}$ versus $\left[\mathrm{Fe}_{3} \mathrm{O}_{4}\right] /\left[\right.$ surfactant coated $\left.\mathrm{Fe}_{3} \mathrm{O}_{4}\right]$. (a) $=\left[\mathrm{Fe}_{3} \mathrm{O}_{4}\right]$, (b) $=\left[\mathrm{CTABr} @ \mathrm{Fe}_{3} \mathrm{O}_{4}\right.$, and (c) $=\left[\mathrm{SDS} @ \mathrm{Fe}_{3} \mathrm{O}_{4}\right]$. Reaction conditions: [Tetracaine $]=4.0 \times 10^{-5} \mathrm{~mol} \mathrm{dm}^{-3},[\mathrm{NaOH}]=5.0 \times 10^{-2} \mathrm{~mol} \mathrm{dm}^{-3}$ and Temperature $=37^{\circ} \mathrm{C}$.

Effect of Surfactant-Modified Iron Nanoparticles and Polyethylene glycol mixture on the Alkaline Hydrolysis of Tetracaine

Fig. 9 shows the trend in deviation for the reaction rate constant values with increment in the amount of the surfactant coated $\mathrm{Fe}_{3} \mathrm{O}_{4}$. Therefore, the reaction rate constant values show a greater inhibitive effect for $\mathrm{SDS} @ \mathrm{Fe}_{3} \mathrm{O}_{4}$ as compared to $\mathrm{CTABr} @ \mathrm{Fe}_{3} \mathrm{O}_{4}$. The mechanism of the reaction is assumed to be the same as proposed in Scheme 1and the observed results were treated using the relationship given in equation (9). The values of rate constant and equilibrium constant for surfactant coated $\mathrm{Fe}_{3} \mathrm{O}_{4}$ are given in Table 1. The higher values of equilibrium constant for the binding of tetracaine with SDS than $\mathrm{CTABr}$ suggest that more tetracaine molecules are adsorbed with SDS coated $\mathrm{Fe}_{3} \mathrm{O}_{4}$. The reaction rate constant values decreased with increase in the amount of polyethylene glycols (PEG) of molecular weights of 1500 , 4000, 6000 and 8000 in the presence CTABr@ $@ \mathrm{Fe}_{3} \mathrm{O}_{4}$ and SDS@ $\mathrm{Fe}_{3} \mathrm{O}_{4}$ nanoparticles. The amount of SDS@ $\mathrm{Fe}_{3} \mathrm{O}_{4}$ and $\mathrm{CTABr} @ \mathrm{Fe}_{3} \mathrm{O}_{4}$ was increased from 0.02 to $0.4 \%$ (w/v) at a constant polyethylene glycol concentration that is $1 \%$ $(\mathrm{w} / \mathrm{v})$. The concentrations of tetracaine $\left(4.0 \times 10^{-5} \mathrm{~mol} \mathrm{dm}^{-3}\right)$ and sodium hydroxide $\left(5.0 \times 10^{-2} \mathrm{~mol} \mathrm{dm}^{-3}\right)$ were kept constant at $37{ }^{\circ} \mathrm{C}$ respectively. The change in rate constant values against the varying amount of $\mathrm{SDS} @ \mathrm{Fe}_{3} \mathrm{O}_{4}$ and $\mathrm{CTABr} @ \mathrm{Fe}_{3} \mathrm{O}_{4}$, are given in Table 2 and Table 3 respectively. The values of equilibrium constant and reaction rate constant obtained at varying concentration of SDS@ $\mathrm{Fe}_{3} \mathrm{O}_{4}$ and $\mathrm{CTABr} @ \mathrm{Fe}_{3} \mathrm{O}_{4}$ at a fixed PEG concentration of different molecular weights are given in Table 4. The increase in the concentration of PEG at fixed $\mathrm{CTABr} @ \mathrm{Fe}_{3} \mathrm{O}_{4}$ and SDS@ $\mathrm{Fe}_{3} \mathrm{O}_{4}$ also decreased reaction rate for the hydrolysis of tetracaine. The values of equilibrium constant and rate constant obtained at these PEG concentrations and at fixed amount of surfactant coated iron nanoparticles (SDS@ $\mathrm{Fe}_{3} \mathrm{O}_{4}$ and $\left.\mathrm{CTABr} @ \mathrm{Fe}_{3} \mathrm{O}_{4}\right)$ are given in Tables 5-6.
Table 2. Variation in the values of rate constant $\left(\mathrm{k}_{\mathrm{obs}}\right)$ as a function of amount of SDS@ $\mathrm{Fe}_{3} \mathrm{O}_{4}$ in the presence of $1.0 \%$ (w/v) PEGs of different molecular weights.

\begin{tabular}{ccccc}
\hline $\mathbf{1 0}^{2}\left[\mathrm{SDS} @ \mathrm{Fe}_{\mathbf{3}} \mathbf{O}_{4}\right]$ & \multicolumn{4}{c}{$\mathbf{1 0}^{\mathbf{4}} \mathbf{k}_{\mathbf{o b s}}\left(\mathbf{s}^{\mathbf{- 1}}\right)$} \\
\cline { 2 - 5 }$(\boldsymbol{\%} \mathbf{w}) \mathbf{v})$ & PEG & PEG & PEG & PEG \\
& $\mathbf{1 5 0 0}$ & $\mathbf{4 0 0 0}$ & $\mathbf{6 0 0 0}$ & $\mathbf{8 0 0 0}$ \\
\hline 0 & 4.01 & 4.01 & 4.01 & 4.01 \\
2 & 3.01 & 2.3 & 1.7 & 1.2 \\
10 & 1.9 & 1.52 & 0.925 & 0.52 \\
20 & 1.37 & 1.1 & 0.75 & 0.39 \\
30 & 1.21 & 0.955 & 0.622 & 0.33 \\
40 & 1.1 & 0.878 & 0.455 & 0.233 \\
\hline
\end{tabular}

Reaction conditions: [Tetracaine $]=4.0 \times 10^{-5} \mathrm{~mol} \mathrm{dm}^{-3},[\mathrm{NaOH}]=5.0 \times 10^{-2} \mathrm{~mol}$ $\mathrm{dm}^{-3}$ and Temperature $=37^{\circ} \mathrm{C}$

Table 3. Variation in the values of rate constant $\left(\mathrm{k}_{\mathrm{obs}}\right)$ as a function of amount of CTABr@ $\mathrm{Fe}_{3} \mathrm{O}_{4}$ in the presence of $1.0 \%$ (w/v) PEGs of different molecular weights.

\begin{tabular}{ccccc}
\hline $\mathbf{1 0}^{\mathbf{2}}$ & \multicolumn{4}{c}{$\mathbf{1 0}^{\mathbf{4}} \mathbf{k}_{\mathbf{o b s}}\left(\mathbf{s}^{\mathbf{- 1}}\right)$} \\
\cline { 2 - 5 }$\left[\mathbf{C T A B r} @ \mathrm{Fe}_{3} \mathbf{O}_{\mathbf{4}}\right]$ & PEG & PEG & PEG & PEG \\
$(\boldsymbol{\%}$ w/v $)$ & $\mathbf{1 5 0 0}$ & $\mathbf{4 0 0 0}$ & $\mathbf{6 0 0 0}$ & $\mathbf{8 0 0 0}$ \\
\hline 0 & 4.01 & 4.01 & 4.01 & 4.01 \\
2 & 2.5 & 2.1 & 1.35 & 1.2 \\
10 & 1.52 & 0.976 & 0.756 & 0.49 \\
20 & 1.27 & 0.726 & 0.426 & 0.309 \\
30 & 1.12 & 0.615 & 0.342 & 0.214 \\
40 & 1.02 & 0.515 & 0.233 & 0.101 \\
\hline
\end{tabular}

Reaction conditions: $[$ Tetracaine $]=4.0 \times 10^{-5} \mathrm{~mol} \mathrm{dm}^{-3},[\mathrm{NaOH}]=5.0 \times 10^{-2} \mathrm{~mol}$ $\mathrm{dm}^{-3}$ and Temperature $=37^{\circ} \mathrm{C}$.

Table 4. Variation in the values of rate constant $\left(\mathrm{k}_{\mathrm{obs}}\right)$ with the increase in [PEGs] of different molecular weights in the presence of SDS @ $\mathrm{Fe}_{3} \mathrm{O}_{4}$ $(0.1 \% \mathrm{w} / \mathrm{v})$ and $\mathrm{CTABr} @ \mathrm{Fe}_{3} \mathrm{O}_{4}(0.1 \% \mathrm{w} / \mathrm{v})$.

\begin{tabular}{|c|c|c|c|c|c|c|c|c|}
\hline \multirow{3}{*}{$\begin{array}{c}\text { PEG] } \\
\% \\
(w / v)\end{array}$} & \multicolumn{8}{|c|}{$10^{4} k_{\text {obs }}\left(s^{-1}\right)$} \\
\hline & \multicolumn{2}{|c|}{ PEG 1500 } & \multicolumn{2}{|c|}{ PEG 4000 } & \multicolumn{2}{|c|}{ PEG 6000 } & \multicolumn{2}{|c|}{ PEG 8000 } \\
\hline & $\begin{array}{l}\mathrm{SDS} @ \\
\mathrm{Fe}_{3} \mathrm{O}_{4}\end{array}$ & $\begin{array}{c}\mathrm{CTABr} \\
@ \\
\mathrm{Fe}_{3} \mathrm{O}_{4} \\
\end{array}$ & $\begin{array}{c}\mathrm{SDS} \\
@ \\
\mathrm{Fe}_{3} \mathrm{O}_{4} \\
\end{array}$ & $\begin{array}{c}\mathrm{CTA} \\
\mathrm{Br} @ \\
\mathrm{Fe}_{3} \mathrm{O}_{4} \\
\end{array}$ & $\begin{array}{c}\mathrm{SDS} @ \\
\mathrm{Fe}_{3} \mathrm{O}_{4}\end{array}$ & $\begin{array}{c}\mathrm{CTA} \\
\mathrm{Br} @ \\
\mathrm{Fe}_{3} \mathrm{O}_{4} \\
\end{array}$ & $\begin{array}{l}\mathrm{SDS} @ \\
\mathrm{Fe}_{3} \mathrm{O}_{4}\end{array}$ & $\begin{array}{c}\mathrm{CTABr} \\
@ \\
\mathrm{Fe}_{3} \mathrm{O}_{4} \\
\end{array}$ \\
\hline 0 & 4.01 & 4.01 & 4.01 & 4.01 & 4.01 & 4.01 & 4.01 & 4.01 \\
\hline 0.5 & 2.5 & 2.25 & 2.3 & 1.8 & 2.1 & 1.5 & 1.8 & 1.3 \\
\hline 1 & 1.85 & 1.52 & 1.61 & 1.1 & 1.41 & 0.756 & 1.2 & 0.49 \\
\hline 1.5 & 1.63 & 1.3 & 1.25 & 0.825 & 1.1 & 0.645 & 0.75 & 0.35 \\
\hline 2 & 1.52 & 1.2 & 1.13 & 0.777 & 0.825 & 0.522 & 0.52 & 0.28 \\
\hline 2.5 & 1.41 & 1.1 & 1.07 & 0.678 & 0.666 & 0.42 & 0.23 & 0.22 \\
\hline
\end{tabular}

Reaction conditions: [Tetracaine] $=4.0 \times 10^{-5} \mathrm{~mol} \mathrm{dm}^{-3},[\mathrm{NaOH}]=5.0 \times 10^{-2} \mathrm{mo}$ $\mathrm{dm}^{-3}$ and Temperature $=37^{\circ} \mathrm{C}$

Table 5. Variation in the values of $\mathrm{K}_{\mathrm{e}}$ and $\mathrm{k}_{\mathrm{MNPs}}$ with the change in the amount of $\mathrm{CTABr} @ \mathrm{Fe}_{3} \mathrm{O}_{4}$ and $\mathrm{SDS} @ \mathrm{Fe}_{3} \mathrm{O}_{4}$ in the presence of fixed [PEGs].

\begin{tabular}{|c|c|c|c|c|c|c|c|c|}
\hline \multirow{2}{*}{$\begin{array}{l}\text { Kinetic } \\
\text { Paramete }\end{array}$} & \multicolumn{2}{|c|}{ PEG1500 } & \multicolumn{2}{|c|}{ PEG4000 } & \multicolumn{2}{|c|}{ PEG6000 } & \multicolumn{2}{|c|}{ PEG8000 } \\
\hline & $\begin{array}{c}\overline{\mathrm{CTABr}} \\
@ \\
\mathrm{Fe}_{3} \mathrm{O}_{4} \\
\end{array}$ & $\begin{array}{c}\text { SDS } \\
@ \\
\mathrm{Fe}_{3} \mathrm{O}_{4} \\
\end{array}$ & $\begin{array}{c}\mathrm{CTABr} \\
@ \\
\mathrm{Fe}_{3} \mathrm{O}_{4} \\
\end{array}$ & $\begin{array}{c}\text { SDS } \\
@ \\
\mathrm{Fe}_{3} \mathrm{O}_{4} \\
\end{array}$ & $\begin{array}{c}\mathrm{CTABr} \\
@ \\
\mathrm{Fe}_{3} \mathrm{O}_{4} \\
\end{array}$ & $\begin{array}{c}\text { SDS } \\
@ \\
\mathrm{Fe}_{3} \mathrm{O}_{4} \\
\end{array}$ & $\begin{array}{c}\text { CTABr } \\
@ \\
\mathrm{Fe}_{3} \mathrm{O}_{4} \\
\end{array}$ & $\begin{array}{c}\mathrm{SDS} \\
@ \\
\mathrm{Fe}_{3} \mathrm{O}_{4} \\
\end{array}$ \\
\hline $\mathrm{K}_{\mathrm{s}}$ & 51.4 & 23 & 49.3 & 26.6 & 45.9 & 96.2 & 130 & 145 \\
\hline $10^{5} \mathrm{k}_{\mathrm{m}}\left(\mathrm{s}^{-1}\right)$ & 9.45 & 8.47 & 3.69 & 5.66 & 4.63 & 5.13 & 1.30 & 2.39 \\
\hline $\mathrm{R}^{2}$ & 0.998 & 0.998 & 0.988 & 0.999 & 0.994 & 0.983 & 0.985 & 0.993 \\
\hline
\end{tabular}

Reaction conditions: [Tetracaine] $=4.0 \times 10^{-5} \mathrm{~mol} \mathrm{dm}^{-3}[\mathrm{NaOH}]=5.0 \times 10^{-2} \mathrm{~mol}$ $\mathrm{dm}^{-3}[\mathrm{PEG}]=1 \% \mathrm{w} / \mathrm{v}$ and Temperature $=37^{\circ} \mathrm{C}$.

Table 6. Variation in the values of $\mathrm{K}_{\mathrm{e}}$ and $\mathrm{k}_{\mathrm{MNPs}}$ with the change in [PEGs] in the presence of fixed amount of CTABr@ $\mathrm{Fe}_{3} \mathrm{O}_{4}$ and $\mathrm{SDS} @ \mathrm{Fe}_{3} \mathrm{O}_{4}$

\begin{tabular}{|c|c|c|c|c|c|c|c|c|}
\hline \multirow{2}{*}{$\begin{array}{l}\text { Kinetic } \\
\text { Parameter }\end{array}$} & \multicolumn{2}{|c|}{ PEG1500 } & \multicolumn{2}{|c|}{ PEG4000 } & \multicolumn{2}{|c|}{ PEG6000 } & \multicolumn{2}{|c|}{ PEG8000 } \\
\hline & $\begin{array}{c}\text { CTAB } \\
\text { r@ } \\
\mathrm{Fe}_{3} \mathrm{O}_{4}\end{array}$ & $\begin{array}{c}\mathrm{SDS} \\
@ \\
\mathrm{Fe}_{3} \mathrm{O}_{4}\end{array}$ & $\begin{array}{c}\text { CTAB } \\
\text { r@ } \\
\mathrm{Fe}_{3} \mathrm{O}_{4}\end{array}$ & $\begin{array}{c}\mathrm{SDS} \\
@ \\
\mathrm{Fe}_{3} \mathrm{O}_{4}\end{array}$ & $\begin{array}{c}\mathrm{CTAB} \\
\mathrm{r} @ \\
\mathrm{Fe}_{3} \mathrm{O}_{4}\end{array}$ & $\begin{array}{c}\mathrm{SDS} \\
@ \\
\mathrm{Fe}_{3} \mathrm{O}_{4}\end{array}$ & $\begin{array}{c}\text { CTAB } \\
\text { r@ } \\
\mathrm{Fe}_{3} \mathrm{O}_{4}\end{array}$ & $\begin{array}{l}\mathrm{SDS@} @ \\
\mathrm{Fe}_{3} \mathrm{O}_{4}\end{array}$ \\
\hline $\mathrm{K}_{\mathrm{s}}$ & 197 & 177 & 385 & 218 & 567 & 170 & 756 & 141 \\
\hline $10^{5} \mathrm{k}_{\mathrm{m}}\left(\mathrm{s}^{-1}\right)$ & 4.22 & 7.58 & 3.27 & 4.79 & 2.03 & 0.969 & 0.263 & 0.784 \\
\hline $\mathrm{R}^{2}$ & 0.985 & 0.990 & 0.972 & 0.974 & 0.949 & 0.993 & 0.998 & 0.994 \\
\hline
\end{tabular}

Reaction conditions: [Tetracaine] $=4.0 \times 10^{-5} \mathrm{~mol} \mathrm{dm}^{-3}[\mathrm{NaOH}]=5.0 \times 10^{-2} \mathrm{~mol} \mathrm{dm}^{-3}$, $\mathrm{CTABr} @ \mathrm{Fe}_{3} \mathrm{O}_{4}$ and $\mathrm{SDS} @ \mathrm{Fe}_{3} \mathrm{O}_{4}$ at $(0.1 \% \mathrm{w} / \mathrm{v})$ and Temperature $=37^{\circ} \mathrm{C}$. 


\section{Advanced Materials Letters www.vbripress.com/aml}

\section{Conclusion}

The iron oxide nanoparticles were synthesized by coprecipitation method and the synthesized material was characterized by different physical techniques. The XRD patterns showed the crystalline nature of the material. The appearance of additional band at $1252 \mathrm{~cm}^{-1}$ ensured the coatings of iron nanoparticles with SDS. Similarly, the band at $960 \mathrm{~cm}^{-1}, 1395 \mathrm{~cm}^{-1}$, and $1465 \mathrm{~cm}^{-1}$ confirmed the coating of materials by $\mathrm{CTABr}$. The rates of reaction for the alkaline hydrolysis of tetracaine was found to be independent on [tetracaine] but increased linearly with the increment in the $[\mathrm{NaOH}]$. The increase in the amount of $\mathrm{Fe}_{3} \mathrm{O}_{4}$ decreased the rate of reaction. The decreasing effect on the rate of reaction for the hydrolysis of tetracaine was observed on increasing the concentration of $\mathrm{CTABr}$ and SDS in the presence of $\mathrm{Fe}_{3} \mathrm{O}_{4}$. The same trend of decrease in the rate of reaction was followed on increasing the amount of surfactant coated $\mathrm{Fe}_{3} \mathrm{O}_{4}$ nanoparticles. The added PEGs solution in the presence of $\mathrm{Fe}_{3} \mathrm{O}_{4}$ and surfactant coated $\mathrm{Fe}_{3} \mathrm{O}_{4}$ displayed inhibitive effect on the reaction rate. The analysis of the kinetic results showed the higher binding ability of tetracaine with $\mathrm{Fe}_{3} \mathrm{O}_{4}$ nanoparticles and with surfactant coated $\mathrm{Fe}_{3} \mathrm{O}_{4}$ nanoparticles. These findings can be further explored to use $\mathrm{Fe}_{3} \mathrm{O}_{4}$ nanoparticles and surfactant coated $\mathrm{Fe}_{3} \mathrm{O}_{4}$ nanoparticles as drug carrier. Further, the study establishes that the drug is more stabile in the presence of these nanoparticles.

\section{Acknowledgments}

The authors are thankful to UGC, New Delhi for providing scholarship and contingency for the progress of the research work.

\section{Keywords}

Base catalysed hydrolysis of tetracaine, $\mathrm{Fe}_{3} \mathrm{O}_{4}$ magnetic nanoparticles, $\mathrm{SDS} @ \mathrm{Fe}_{3} \mathrm{O}_{4}, \mathrm{CTABr} @ \mathrm{Fe}_{3} \mathrm{O}_{4}$

\section{Received: 6 July 2020}

Revised: 18 July 2020

Accepted: 21 July 2020

\section{References}

1. Godoi, M.; Liz, D. G.; Ricardo, E. W.; Rocha, M. S. T.; Azeredo, J. B.; Braga, A. L.; Tetrahedron, 2014, 70, 3349.

2. Kumar, A.; Gupta, M.; Biomaterials, 2005, 26, 3995.

3. Alishiri, T.; Oskooei, H. A.; Heravi, M. M.; Synth. Commun., 2013, 43, 3357.

4. Teja, A. S.; Koh, P. Y.; Prog. Cryst. Growth Charact. Mater., 2009, $55,22$.

5. Gonzales, M.; Krishnan, K. M.; J. Magn. Magn. Mater., 2005, 293, 265.

6. Ai, H.; Flask, C.; Weinberg, B.; Shuai, X. T.; Pagel, M. D.; Farrell, D.; Duerk, J.; Gao, J.; Adv. Mater., 2005, 17, 1949.

7. Jurgons, R.; Seliger, C.; Hilpert, A.; Trahms, L.; Odenbach, S.; Alexiou, C.; J. Phys. Condens. Matter, 2006, 18, S2893.

8. Tartaj, P.; M. a del P. Morales; Veintemillas-Verdaguer, S.; Gonz lez-Carre o, T.; Serna, C. J.; J. Phys. D. Appl. Phys., 2003, 36, R182.

9. Mamani, J. B.; Gamarra, L. F.; de S. Brito, G. E.; Mater. Res., 2014, 17,542 .

10. Huang, J.; Wang, Y.; Hao, Z.; Peng, X.; J. Saudi Chem. Soc., 2017, $21,811$.

11. Kim, D. K.; Mikhaylova, M.; Wang, F. H.; Kehr, J.; Bjelke, B.; Zhang, Y.; Tsakalakos, T.; Muhammed, M.; Chem. Mater., 2003, 15, 4343.
12. Kohler, N.; Sun, C.; Wang, J.; Zhang, M.; Langmuir, 2005, 21, 8858.

13. Zhang, J. L.; Srivastava, R. S.; Misra, R. D. K.; Langmuir, 2007, 23, 6342.

14. Kievit, F. M.; Veiseh, O.; Bhattarai, N.; Fang, C.; Gunn, J. W.; Lee, D.; Ellenbogen, R. G.; Olson, J. M.; Zhang, M.; Adv. Funct. Mater., 2009, 19, 2244

15. Brechner, V. L.; Cohen, D. D.; Pretsky, I.; Ann. N. Y. Acad. Sci., 1967, 141, 524.

16. Deupree, J.; xPharm: The Comprehensive Pharmacology Reference, Elsevier, 2007, 1.

17. Foldvari, M.; Gesztes, A.; Mezei, M.; Cardinal, L.; Kowalczyk, I.; Behl, M.; Drug Dev. Ind. Pharm., 1993, 19, 2499.

18. Rawat, M.; Singh, D.; Saraf, S.; Biol. Pharm. Bull., 2006, 29, 1790.

19. De Jong, W.H.; Borm, P.J.A.; Int. J. Nanomedicine, 2008, 3, 133.

20. Ochekpe, N.A.; Olorunfemi, P.O.; Ngwuluka, N.; Trop. J. Pharm. Res., 2009, 8, 265.

21. Ochekpe, N.A.; Olorunfemi, P.O.; Ngwuluka, N.; Trop. J. Pharm. Res., 2009, 8, 275.

22. Márquez, F.; Herrera, G. M.; Campo, T.; Cotto, M.; Ducongé, J.; Sanz, J. M.; Elizalde, E.; Perales, Ó.; Morant, C.; Nanoscale Res. Lett., 2012, 7, 210.

23. Li, M. Y.; Sui, X. D.; Key Eng. Mater., 2012, 82, 512.

24. Azcona, P.; Zysler, R.; Lassalle, V.; Colloids Surfaces A Physicochem. Eng. Asp., 2016, 504, 320.

25. López, J.; González, F.; Bonilla, F.; Zambrano, G.; Gomez, M.; Synthesis and characterization of $\mathrm{Fe} 3 \mathrm{O} 4$ magnetic nanofluid, 2010, Vol. 30 .

26. Saranya, T.; Parasuraman, K.; Anbarasu, M.; Balamurugan, K.; Nano Vis., 2015, 5, 149.

27. Aliramaji, S.; Zamanian, A.; Sohrabijam, Z.; Procedia Mater. Sci., 2015, 11, 265.

28. Saif, B.; Wang, C.; Chuan, D.; Shuang, S.; J. Biomater. Nanobiotechnol., 2015, 6, 267.

29. Elfeky, S. A.; Ebrahim, S.; Fahmy, A.; J. Adv. Res., 2017, 8, 435.

30. Heidari A.; Noshin Mir.; Reza Nikkaran, Ali; J. Nanostruct., 2016 , 6, 199.

31. Azari, Z.; Pourbasheer, E.; Beheshti, A.; Spectrochim. Acta - Part A Mol. Biomol. Spectrosc., 2016, 153, 599.

32. Bavili Tabrizi, A.; Dehghani Teymurlouie, N.; J. Mex. Chem. Soc., 2018, 60, 108

33. Mahmoudi, M.; Simchi, A.; Imani, M.; Ha, U. O.; J. Phys. Chem. C, 2009, 113, 8124 . 